\title{
A AUTONOMIA DAS AGÊNCIAS REGULADORAS E A ESTABILIDADE DE SEUS DIRIGENTES
}

\author{
José ALBERTo BUCHEB*
}

1. Considerações iniciais - 2. A estabilidade dos dirigentes das agências reguladoras - 3. Os controles externo e interno das atividades das agências reguladoras - 4. Considerações acerca dos modelos adotados no exterior - 5. As propostas de alterações legislativas em tramitação na Câmara e no Senado - 6. Conclusão. Referências Bibliográficas.

\section{Considerações iniciais}

O tema da autonomia das agências reguladoras vem sendo objeto de debate desde a criação desses organismos, na segunda metade dos anos 90. As agências foram concebidas, na legislação que as criou, como autarquias especiais, cuja principal característica é a independência em relação à Chefia do Poder Executivo.

Este modelo de administração de serviços públicos teve por inspiração o paradigma em vigor nos Estados Unidos e em alguns países europeus e se aplica também às atividades econômicas monopolizadas pelo Estado em face de seu relevante interesse coletivo, como é o caso das atividades de exploração e produção de petróleo e gás natural.

O ponto comum a todos os autores que se dedicaram ao estudo das agências reguladoras é a importância conferida à independência ou à autonomia destes organismos':

"o jurista espanhol Gaspar Ariño, por exemplo, enfatiza que 'as duas notas fundamentais que as caracterizam - suas duas grandes vantagens - são

* Advogado. Mestre em Direito Internacional e Integração Econômica pela UERJ/FDIR. Doutorando em Legislação do Petróleo pela UERJ/FGEL.

1 Mendes. Conrado Hübner, Reforma do Estado e Agências Reguladoras: Estabelecendo os Parâmetros de Discussāo, in Direito Administrativo Econômico, Malheiros, 2000, Sundfeld, Carlos 
a especialização e a independência'. Um pouco mais adiante em seu texto, continua: 'a independência de juízo e a de decisão resultam particularmente necessárias nestas matérias por razões fundamentais: primeiro porque para o politico o mais fácil é adiar o problema; segundo porque nos encontramos diante de situações que afetam diretamente os direitos e liberdades dos cidadãos, onde as decisões devem ser tomadas com a imparcialidade $e$ independência de um juiz"?

Nessa linha, alguns autores, como Floriano Azevedo MARQUES NETO não admitem, sequer, a figura do contrato de gestão, concebida no Direito francês, e que constitui o mecanismo pelo qual "o estado outorga alguma autonomia a um ente público. fixxando, de outro lado: i) metas que devam ser atingidas; ii) sanções apenatórias ou premiais - aos dirigentes em caso de descumprimento ou atingimento de tais metas" 3 .

De modo geral, para justificar-se a necessidade de independência ou autonomia das agências reguladoras, busca-se, tácita ou expressamente, desqualificar o "político" - movido quase sempre pelo interesse meramente eleitoral - e supervalorizar o "técnico" - este sim, merecedor da confiança da sociedade.

Nesse contexto, e dentro desses pressupostos, foram criadas as agências reguladoras brasileiras ${ }^{4}$. No setor do petróleo, por exemplo, a Lei $n^{0} 9.478$ (Lei do

2 GASPAR, Ariño, 1993, Economia y Estado, Buenos Aires, Abeledo-Perrot, p. 470 apud Mendes, Conrado Hübner, Reforma do Estado e Agências Reguladoras: Estabelecendo os Parâmetros de Discussão, in Direito Administrativo Econômico, Malheiros. 2000, Sundfeld, Carlos Ari (Coordenador), p. 124. No mesmo sentido posicionaram-se Luis Roberto BARROSO: "A instituição de um regime jurídico especial visa a preservar as agências reguladoras de ingerências indevidas. inclusive e sobretudo, como assinalado. por parte do Estado e de seus agentes. Procurou-se demarcar, por esta razão, um espaço de legítima discricionariedade, com predomínio de juízos técnicos sobre as valorações políticas. Constatada a necessidade de se resguardarem essas autarquias especiais de injunçōes externas inadequadas, foram-lhes outorgadas autonomia político-administrativa e autonomia econômico-financeira". (Agências reguladoras. Constituição, transformaçōes do Estado e legitimidade democrática. R. Dir. Adm., 229: 285-311, Jul./Set. 2002, p. 296); e Floriano Azevedo Marques Neto: "Um exemplo parece ser ilustrativo. Deve o órgão regulador deter sutīciente independência (apoiada pelos instrumentos legais adequados) para se opor ao interesse de um governante que, numa jogada eleitoral, intente reduzir à metade as tarifas praticadas para um determinado serviço essencial. A independência, aqui, deve servir para que o órgão regulador seja um instrumento de política governamental, e não um instrumento de política de um governo". (MARQUES NETO, Floriano Azevedo, A Nova Regulaçăo Estatal e as Agências Independentes, in Direito Administrativo Econômico, Malheiros. 2000, Sundfeld, Carlos Ari (Coordenador), p. 87).

3 Marques Neto. Floriano Azevedo, A Nova regulaşão Estatal e as Agências Independentes, in Direito Administrativo Econômico, Malheiros, 2000, Sundfeld, Carlos Ari (Coordenator), p. 88-89.

4 BARROSO, Luís Roberto. observa que "até o início de 2002, haviam sido criadas no país as seguintes agências: a Agência Nacional de Telecomunicações - ANATEL. prevista na Lei 9.472, de 16.07.97: a Agência Nacional de Energia Elétrica - ANEEL, instituída pela Lei 9.427, de 26.12.96; a Agência Nacional do Petróleo - ANP, que foi instituida pela Lei 9.478, de 6.08.97; a Agência Nacional de Vigilância Sanitária (Lei 9.782, de 26.01.99); a Agência Nacional de Saúde Suplementar - ANS (Lei 9.961, de 28.01.2000), a Agência Nacional de Águas - ANA (Lei 9.984, 
Petróleo), de 6 de agosto de 1997, instituiu a Agência Nacional do Petróleo - ANP. De acordo com o art. $7^{\circ}$ da referida lei, a ANP é uma entidade integrante da Administração Federal indireta, submetida ao regime autárquico especial, como órgão regulador da indústria do petróleo, vinculado ao Ministério de Minas e Energia. Nos artigos $8^{\circ}, 9^{\circ}$ e 10 são definidas as atribuições da ANP. Os artigos 11 e 14 cuidam da estrutura organizacional, os artigos 15 e 16, das receitas e do acervo e os artigos 17 a 20 , do processo decisório da autarquia.

\section{A estabilidade dos dirigentes das agências reguladoras}

Os requisitos essenciais à independência ou autonomia político-institucional das agências reguladoras com mais freqüência enumerados pela doutrina são listados a seguir ${ }^{5}$ :

1. estabilidade dos dirigentes: impossibilidade de demissão, salvo falta grave apurada mediante devido processo legal;

2. mandato fixo;

3. nomeação de diretores com lastro político:

4. impossibilidade de recurso administrativo ao Ministério a que estiver vinculada: inexistência de instância revisora hierárquica dos seus atos, ressalvada a revisão judicial:

5. autonomia de gestão: não-vinculação hierárquica a qualquer instância de governo;

6. estabelecimento de fontes próprias de recursos para o órgão, se possível geradas do próprio exercício da atividade regulatória.

Mais precisamente, o requisito fundamental para configurar-se a autonomia das agências reguladoras foi destacado com extrema objetividade por Carlos Ari Sundfeld ${ }^{6}$ :

de 17.07.2000), e as recentes Agência Nacional de Transportes Terrestres - ANTT e Agência Nacional de Transportes Aquaviários - ANTAQ, ambas criadas pela Lei $n^{\circ} 10.233$, de 5.06.2001. A Comissão de Valores Mobiliários, que para muitos já era unna agência reguladora, recebeu da Lei $n^{\circ} 10.411$ de 26.02.2002 maior grau de autonomia, incluindo mandatos estáveis para seus dirigentes." BARROSO, Luís Roberto, 2002, Agências reguladoras. Constituiçāo, transformaçōes do Estado e legitimidade democrática. R. Dir. Adm., 229: 285-311, Jul./Set. 2002, p. 294.

5 Ver a respeito: BARROSO, Luís Roberto, 2002, Agências reguladoras. Constituição, transformações do Estado e legitimidade democrática. R. Dir. Adm.. 229: 285-311, Jul./Set. 2002, p. 296-297: MENDES. Conrado Hübner, Reforma do Estado e Agências Reguladoras: Estabelecendo os Parâmetros de Discussão, in Direito Administrativo Econômico. Malheiros, 2000. SUNDFELD, Carlos Ari (Coordenador), p. 126; e MARQUES NETO, Floriano Azevedo, A Nova regulação Estatal e as Agências Independentes, in Direito Administrativo Econômico, Malheiros, 2000, SUNDFELD. Carlos Ari (Coordenador), p. 88.

6 SUNDFELD, Carlos Ari. Introdução ìs agêncials reguladoras, in Direito Administrativo Econômicu. Malheiros, 2000. SUNDFELD. Carlos Ari (Cuordenador). p. 24-25. No inesmo sentido, o comentário de Jorge Luis SALOMONI: "as autoridades independentes se caracterizam por duas notas fundamentais: independência em reliç̧ão ao governo e neutralidade política de sua gestão. 
"na realidade, o fator fundamental para garantir a autonomia da agência parece estar na estabilidade dos dirigentes. Na maior parte das agências atuais o modelo vem sendo o de estabelecer mandatos. O Presidente da República, no caso das agências federais, escolhe os dirigentes e os indica ao Senado Federal, que os sabatina e aprova (o mesmo sistema usado para os Ministros do Supremo Tribunal Federal); uma vez nomeados, eles exercem mandato, não podendo ser exonerados 'ad nutum'; isso é o que garante efetivamente a autonomia".

Neste diapasão, o art. 12 da Lei do Petróleo, cuja redação é reproduzida a seguir, tratava da estabilidade dos dirigentes da ANP, mas foi vetado pelo então Presidente da República Fernando Henrique Cardoso:

\section{“Art. 12. Os membros da Diretoria da ANP somente poderão ser exonerados em razão de:}

I - condenação penal, transitada em julgado;

II - prática de ato de improbidade apurado em processo administrativo;

III - violação administrativa grave ou descumprimento manifesto de suas atribuições, reconhecidos em decisão fundamentada do Senado Federal, por provocação do Presidente da República.

Parágrafo único. Nas hipóteses deste artigo, o Presidente da República poderá afastar temporariamente do cargo o Diretor sob investigaçāo, até decisão final do Senado Federal."

Na Mensagem n 870 , de 6 de agosto de 1997, do Presidente da República ao Presidente do Senado Federal $^{7}$ são apresentadas as razões do veto:

"Por inconstitucional, pois o inciso III do art. 12 condiciona a exoneração de membros da Diretoria da ANP pelo Presidente da República ao reconhecimento pelo Senado Federal, em decisão fundamentada, numa flagrante ingerência em área de competência privativa do Presidente da República, qual seja a de dispor sobre a organização e o funcionamento da adminis. tração federal (CF art. 84, VI), configurando-se assim infringência ao princípio da independência dos poderes reconhecidos pela Constituição Federal em seu art. $2^{\text {o'. }}$.

(...). Para assegurar a neutralidade da gestão, isto é, para que não atuem de acordo com razões políticas, mas sim técnicas, se thes confere independência orgânica e funcional em relação ao governo, outorgando-lhes distintos tipos de garantias: impossibilidade de remoção de seus membros, proibição de que se lhes dirijam ordens ou instruçōes, recursos próprios etc" (Teoria General de los Servicios Públicos, Buenos Aires, Editorial Ad Hoc/Villela Editor, p. 407 apud MENDES, Conrado Hübner, Reforma do Estado e Agências Reguladoras: Estabelecendo os Parâmetros de Discussão, in Direito Administrativo Econômico, Malheiros, 2000, SUNDFELD, Carlos Ari (Coordenador), p. 135).

7 Publicada no DOU de 7.8.1997. 
O veto ao art. 12 da Lei $\mathrm{n}^{\circ} 9.478 / 97$ foi mantido, e assim os mandatos dos membros da Diretoria da ANP. na sua origem, poderiam ser revogados ad nutum, pelo Presidente da República.

Essa situação perdurou até o advento da Lei $n^{\circ} 9.986$, de 18 de julho de 2000, que tratou do tema da gestão de recursos humanos das Agências Reguladoras. Nesse momento, a ANP já contava com todos os seus cargos de direção preenchidos e se encontrava em pleno funcionamento. $\mathrm{O}$ art. $9^{\circ}$ da Lei $9.986 / 00$, abaixo transcrito, trouxe à tona, novamente, o tema da estabilidade dos dirigentes das agências reguladoras:

"Art. $9^{\circ}$ Os Conselheiros e os Diretores somente perderão o mandato em caso de renúncia, de condenação judicial transitada em julgado ou de processo administrativo disciplinar.

Parágrafo único. A lei de criação da Agência poderá prever outras condições para a perda do mandato."

Desta feita, entretanto, não houve veto presidencial e o princípio consagrado no art. $9^{\circ}$ da Lei $9.986 / 00$ deu contornos definitivos ao requisito de impossibilidade de demissão dos diretores das agências, essencial à autonomia político-administrativa das chamadas "autarquias especiais", tornando sem efeito, em termos práticos, dispositivos como a regra contida no art. $7^{\circ}$ da Lei da Petróleo que define a ANP como órgão vinculado ao Ministério de Minas e Energia.

$\mathrm{Na}$ realidade, anteriormente ao advento da Lei $n^{\circ} 9.986 / 00$, a questão da imposição de restrição ao Chefe do Poder Executivo para demitir dirigentes de agências reguladoras já havia sido examinada pelo STF, na medida liminar requerida na ação direta de inconstitucionalidade ajuizada pelo Governador do Estado do Rio Grande do Sul contra os artigos $7^{\circ}$ e $8^{\circ}$ da Lei estadual 10.931/97, que criou a Agência Estadual de Regulação dos Serviços Públicos Delegados do Rio Grande do Sul AGERGS ${ }^{8}$. O art. $8^{\circ}$ da referida lei estatuía que "o conselheiro só poderá ser destituído, no curso de seu mandato, por decisão da Assembléia Legislativa”.

8 Controle Concentrado e Vácuo Legislativo: Concluído o julgamento de medida liminar em ação direta de inconstitucionalidade ajuizada pelo Governador do Estado do Rio Grande do Sul contra os artigos $7^{\circ}$ e $8^{\circ}$ da Lei estadual 10.931/97, que criou a Agência Estadual de Regulação dos Serviços Públicos Delegados do Rio Grande do Sul - AGERGS (v. Informativo STF 144). Por aparente ofensa ao princípio da separação dos Poderes (CF, art. $2^{\circ}$ ), o Tribunal deferiu o pedido de medida liminar para suspender, até decisão final da açĩo, a eficácia do art. $8^{\circ}$ da Lei estadual $10.931 / 97$ ("O conselheiro só poderá ser destituído, no curso de seu mandato, por decisão da Assembléia Legislativa."), na redaçāo que lhe deu o art. $1^{\circ}$ da Lei estadual $11.292 / 98$, assim como na sua redação original. Ademais, o Tribunal, considerando que o vazio legislativo decorrente da suspensão desta norma, que é a única forma de demissão prevista na referida Lei, seria mais inconstitucional do que a própria norma impugnada, declarou, por maioria, que a suspensão cautelar do art. $8^{\circ}$ se dava sem prejuízo das restrições à demissibilidade, pelo Governador do Estado, sem justo motivo, consequientes da investidura a termo dos conselheiros da AGERGS, conforme o art. $7^{\circ}$ da Lei 10.931/97 - que condiciona a posse dos conselheiros à prévia aprovação de seus nomes pela Assembléia Legislativa, cujo pedido de suspensão liminar fora indeferido na assentada anterior —. 
As conclusões do STF, em relação ao caso em tela, podem ser assim sumarizadas:

a) a regra contida no art. $8^{\circ}$ da Lei estadual do $\operatorname{RS} n^{\circ} 10.931 / 97$ encerra aparente ofensa ao princípio constitucional da separação dos poderes, pelo que deveria ter sua eficácia suspensa;

b) entretanto, o vazio legislativo decorrente da suspensão desta norma, que contém a única regra de demissão prevista na referida Lei, seria mais inconstitucional do que a própria norma impugnada. daí a razão para que permaneça em vigor até a superveniência de legislação válida":

c) até a superveniência de tal legislação válida, o conselheiro da AGERGS não é demissível ad nutum. mas seu afastamento poderá ser determinado, pelo Governador do Estado, se houver justa motivação para tanto.

É razoável supor que o "motivo justo", mencionado na referida decisão para a demissão do dirigente de agência reguladora, não se limita simplesmente às hipóteses de condenação judicial transitada em julgado e de prática de ato de improbidade apurada em processo administrativo, mas alcança, também, situações como o descumprimento de suas atribuições e a não observância das diretrizes formuladas pelo Poder Executivo.

Em suma, constata-se que as razões do veto presidencial ao art. 12 da Lei do Petróleo e a decisão do STF na ADIn-MC 1.949-RS têm em comum o fato de que em ambas se reconhece que a imposição de restrição à demissibilidade dos dirigentes das agências reguladoras, por parte do Chefe do Poder Executivo, viola o princípio constitucional da independência e harmonia dos poderes. Aliás, é importante assinalar que, por força do inciso III do $\$ 4^{\circ}$ do art. 60 da Constituição Federal, nem mesmo por via de emenda constitucional é possível alteração normativa tendente a abolir a separação dos Poderes. Assim, pelos mesmos fundamentos, pode-se concluir que a regra contida no art. $9^{\circ}$ da Lei $9.986 / 00$ padece de vício de inconstitucionalidade ${ }^{10}$.

Na verdade, o STF já enfrentou essa questão anteriormente, sob a égide da Constituição de 1946, ao decidir, por maioria de votos no Mandado de Segurança $\mathrm{n}^{\circ}$ 8.693, pela possibilidade de o Presidente da República exonerar membros do Conselho Administrativo do Instituto de Aposentadoria e Pensões dos Industriários, apesar de a nomeação para exercício de tal cargo ser por prazo fixo ${ }^{\prime \prime}$.

e também sem prejuízo da superveniência de legislação válida. Vencido em parte o Min. Marco Aurélio. que se limitava à suspensão de eficácia do mencionado art. $8^{\circ}$, por entender que o STF estaria atuando como legislador positivo ao declarar que o conselheiro não seria demissível ad nutum, ou seja, que o seu afastamento só poderia ocorrer mediante justa motivação.

ADInMC 1.949-RS, rel. Min. Sepúlveda Pertence, 18.11.99. (Publicado no Informativo STF, Brasília. 15 at 19 de novembro de $1999-\mathrm{n}^{\circ} 171$.

9 Subentende-se que a mencionada legislação válida detalhará as hipóteses de demissão dos conselheiros da AGERGS pelo Governador do Estado.

10 Como se verá adiante, o instituto da estabilidade dos dirigentes das agências reguladoras enfrenta. ainda, outras dificuldades de naturezat constitucional.

॥ CUÉLLAR, Leila. As agênciass reguladoras e selı poder normativo. Dialética. São Paulo, 2001, 
Em sede doutrinária, a questão da estabilidade dos administradores tem sido tema de estudo de diversos autores. Marcos Juruena Vilela Souto, interpretando o art. 37, 1, da Constituição Federal, argumenta que "se o requisito é a aprovação polítici de profissional de reputação ilibada e notória especialização no setor regulado, não pode haver perda do cargo senão nas hipóteses na lei autorizadas" '? Ocorre, entretanto, que o artigo 37, II da Constituição Federal, determina que a nomeação e a exoneração são livres para cargo em comissão declarado em lei.

E foi justamente com base no princípio contido no Art. 37, II da Constituição Federal, que a Governadora do Estado do Rio Grande do Norte ajuizou Ação Direta de Inconstitucionalidade ${ }^{13}$ contra dispositivos da Lei estadual $n^{0} 7.758 / 99$, que dispõe sobre a Agência de Serviços Públicos do Estado (ARSEP). Nessa ação foi requerida a concessão de medida liminar para a suspensão do art. 10 , parágrafos $1^{\circ}$ e $2^{\circ}$ e do artigo 11 da lei potiguar. $O$ artigo 10 da referida lei estabelece que o diretor-presidente e os diretores-superintendentes da agência são nomeados pelo governador para mandatos não coincidentes de quatro anos. sendo renováveis por mais um período, e o art. 11, que estes dirigentes só perdem os mandatos em caso de prática de atos lesivos ao interesse público. Além da afronta ao "princípio de livre exoneração nos cargos de provimento em comissão". a Governadora do Rio Grande do Norte alega, ainda, que as disposições legais contestadas impedem o executivo estadual de implantar a política pública idealizada para a agência reguladora, com risco de prejuízo aos cofres públicos.

p. 99-100: "o Eminente Ministro Victor Nunes Leal opinou pela impossibilidade de demissão ad nutum, tendo em vista que a investidura de prazo certo, além de objetivar a proteção do servidor contra demissões arbitrárias ou imotivadas, visaria a garantir 'a continuidade de orientação e a independência de ação' dos entes autônomos, permitindo desta forma que seus titulares fịquem protegidos contra as injunções do Chefe do Poder Executivo e 'possam dar plena execução à política adotada pelo Poder Legislativo, ao instituir o órgão autônomo e deferir-lhes as atribuiçôes'. Declara. então, que a garantia de independência do exercício das funçōes de dirigentes do órgão autônomo se concretiza em face de qualquer ocupante da Chetia do Poder Executivo. mesmo contra aquele que tiver feito as nomeações" (Revista de Direito Administrativo. Rio de Janeiro: Fundação Getúlio Vargas, 1963, $n^{\circ} 71,230$ ). Em sentido contrário, o Relator do Mandado de Segurança $n^{\circ} 8.693$. Ministro Ribeiro da Costa: "entendo que o Presidente pode praticar esse ato, pode e deve praticú-lo toda vez que julgar necessário fazê-lo. Não posso compreender que, ao fím do exercício do Poder Executivo, quando estava próximo a inaugurar-se um outro periodo governamental, o Presidente anterior pudesse nomear certos funcionários de sua confiança para exercerem aqueles cargos, invadindo a área de ação do novo Presidente da República, impedindo que o novo Presidente pudesse descortinar os seu programa administrativo, dispondo dos meios necessários a isso, entre os quais avulta. evidentemente, a ação dinâmica dos seus mandatários. que são esses conselheiros, presidentes de institutos, membros de diretorias, elc." (Revista de Direito Administrativo. Rio de Janeiro: Fundaçāo Getúlio Vargas, 1963, n² 71, 215).

12 SOUTO. Marcos Juruena Vilcła, Agência Reguladoras, R. Dir. Adm.. 216: 125-162, 1999. p. 139 apud CUÉLLAR, Leila. As agências reguladoras e seu poder normativo. Dialética. São Paulo. 2001, p. $97-98$.

13 A ADI 2870-7 foi distribuída em 7.4.2003 ao Ministro Moreira Alves. 
Mesmo entre os defensores da autonomia das agências reguladoras encontram-se autores que reconhecem a inconstitucionalidade do instituto da estabilidade de seus dirigentes. Nesse sentido, Leila CUÉLLAR assinala que:

"embora se pretenda garantir a autonomia das agências também através da limitação das hipóteses de exoneração de seus diretores, parece-nos que a impossibilidade de demissão 'ad nutum' dos dirigentes das agências pelo Chefe do Poder Executivo é inconstitucional, porque, ainda que indiretamente, viola o princípio da República, ao possibilitar que pessoa nomeada por um governante, porque de sua confiança, permaneça no exercício das funções para as quais foi designado durante o governo posterior. Sabemos que esta afirmação é perigosa, pois pode vir a desnaturar um pouco a independência que se quer conferir aos entes reguladores. Porém, note-se que a independência da agência não deriva do ato de nomeação de seu dirigente, mas das garantias quanto ao exercicio das prerrogativas que são atribuidas à entidade. Dessa forma, e rigorosamente, a singela substituição do presidente por sujeito que apresente afinidades técnico-políticas com o projeto social (e econômico) da Presidência da República (no caso de agências federais) não implicaria agressão à prestigiada independência das agências reguladoras. Assim, no intuito de reforçar e resguardar a independência política que se pretende conferir às agências, talvez fosse oportuno que se estabelecesse uma 'regra fixa' acerca da substituição dos seus diretores, de governo a governo. Reitere-se, ainda, que a alteração do titular do cargo não viola a independência da agência. Esta continua a ser independente, vez que os demais itens relativos à independência permanecem inalterados".

Nessa linha, Celso Antônio BANDEIRA DE MELLO ${ }^{14}$, um dos críticos mais contundentes do modelo da estabilidade dos dirigentes das agências reguladoras,

14 BANDEIRA DE MELLO, Celso Antônio. Curso de Direito Administrativo, Malheiros., $14^{\mathrm{a}}$ ed., 2002, p. 153-154. Na mesma linha, este autor sustenta ainda o seguinte: "Questão importante é a de saber-se se a garantia dos mandatos por todo o prazo previsto pode ou nāo estender-se além de um mesmo período governamental. Parece-nos evidentíssimo que não. Isto seria o mesmo que engessar a liberdade administrativa do futuro Governo. Ora, é da essência da República a temporariedade dos mandatos, para que o povo, se o desejar, possa eleger novos governantes com orientações políticas e administrativals diversas do Governo precedente. Fora possível a um dado governante outorgar mandatos a pessoas de sua confiança, garantindo-os por um periodo que ultrapassasse a duração de seu próprio mandato, estaria estendendo sua influência para além da época que lhe correspondia (o primeiro mandato de alguns dirigentes da ANATEL é de sete anos) e obstando a que o novo Presidente imprimisse, com a escolha de novos dirigentes, a orientação política e administrativa que foi sufragada nas urnas. Em última instância, seria uma fraude contra o próprio povo (é precisamente isto o que vem sendo feito pelo atual governo [encerrado em 31.12.2002]. Vem criando uma autarquia especial atrás da outra e obviamente sāo nomeadas para dirigi-las pessoas de confiança do grupo que ocupa o Poder, com isto certamente pretende manter o controle da máquina administrativa pública e dos rumos que the tem sido imprimidos, mesmo 
conclui que "a garantia dos mandatos dos dirigentes destas entidades só opera dentro do período governamental em que foram nomeados; encerrado tal período governamental, independentemente do tempo restante para conclusão deles, o novo Governo poderá sempre expelir livremente os que os vinham exercendo".

Em resumo, a independência das agências reguladoras, sustentada pela estabilidade de seus dirigentes, tem como fundamento a presunção absoluta de que as decisões desses dirigentes, ao contrário daquelas tomadas pelos políticos eleitos pela população, têm motivação estritamente técnica e são isentas de eventuais interesses eleitorais. Busca-se, com o instituto da estabilidade, em última análise, "proteger" a sociedade dos governantes por ela mesma eleitos.

\section{Os controles externo e interno das atividades das agências reguladoras}

A discussão acerca da autonomia das agências passa ainda pela análise das funções atribuídas a esses entes da administração indireta. Como sumarizado por Luís Roberto BARROSO ${ }^{15}$. é possível classificar as atividades das agências reguladoras em executivas, decisórias e normativas.

Em relação à função executiva, a Lei do Petróleo (art. $8^{\circ}, \mathrm{I}$ ), por exemplo, estabelece que a ANP deve, dentre outras atribuições, implementar, em sua esfera de atribuições, a política nacional de petróleo e gás, contida na política energética nacional. Essas políticas são propostas ao Presidente da República pelo Conselho Nacional de Política Energética - CNPE, vinculado à Presidência da República e presidido pelo Ministro de Estado de Minas e Energia, nos termos do art. $2^{\circ}$ da Lei do Petróleo. As leis da ANEEL (Lei ${ }^{\circ}$ 9.427/96) e da ANATEL (Lei $n^{\circ}$ 9.472/97) contêm dispositivos similares.

Assim, se o papel das agências é o de executar as políticas formuladas pelos órgãos auxiliares da chefia do Poder Executivo e aprovadas pelo Presidente da República, a questão que se coloca é a de como se dará o controle do Poder Executivo sobre esta função das agências reguladoras. Nesse sentido, Luís Roberto BARRO$\mathrm{SO}^{16}$ observa que nas leis criadoras das agências não há previsão de recurso hierár-

em caso de derrota nas próximas eleições. In [Internet] http://www.migalhas.com.br/mig_imprimir2.aspx?cod_materia= 1041 ). Veja-se a que absurdos conduziria interpretação diversa da ora apresentada como correta: para prolongar a orientação que quisesse imprimir à Administração Pública. inibindo a sobrevinda de diretrizes novas próprias dos que ascendessem nas eleições sucessivas, bastaria ao grupo no Poder transformar todos os principais setores administrativos em entidades comandadas por dirigentes com mandatos - como vem fazendo o atual Governo [encerrado em 31.12.2002] - que ultrapassassem o próprio período. Com isto. mesmo derrotados no pleito eleitoral, persistiriam gerindo o Estado segundo os critérios rejeitados pelos eleitores e obstando a atuação de quem os sucedesse, em antítese absoluta com a idéia de Democracia e de República".

15 BARROSO, Luís Roberto, 2002, Agências reguladoras. Constituiçāo, transformaçōes do Estado e legitimidade democrática. R. Dir. Adm., 229: 285-311, Jul./Set. 2002, p. 301.

16 Barroso, Luis Roberto, 2002, Agências reguladoras. Constituição, transformações do Estado e legitimidade democrática. R. Dir. Adm., 229: 285-311, Jul./Set. 2002, p. 302. 
quico impróprio, contra suas decisões, dirigido à Administração direta ${ }^{17}$, e assim. as agências reguladoras funcionam como última instância administrativa para julgamento dos recursos contra seus atos, "sendo em princípio inadmissível que as decisões tomadas pelas agências possam ser revistas ou modificadas por algum agente político (Ministro ou Secretário de Estado)".

Dessa forma, descartada a via do recurso hierárquico impróprio, conclui-se que a possibilidade de controle das ações dos dirigentes das agências reguladoras, pelo Executivo, limita-se tão-somente à escolha de seus diretores, sendo importante observar que esta escolha será ainda submetida à aprovação do Senado Federal e que o mandato desses diretores, em regra, estende-se além do mandato do Presidente da República que os nomeou.

Ainda em relação ao controle externo dos atos das agências reguladoras, Luís Roberto BARROSO sustenta a tese segundo a qual "escapa às atribuições dos Tribunais de Contas o exame das atividades dessas autarquias especiais quando elas não envolvem dispêndio de recursos públicos" 18 .

E mais, no tocante ao controle judicial, a despeito da norma do inciso XXXV do art. $5^{\circ}$ da Constituição Federal ${ }^{19}$, alguns autores postulam que "o controle judicial do ato administrativo, consoante doutrina tradicional, seria limitado aos aspectos de legalidade. não alcançando o mérito da decisão administrativa" ${ }^{20}$. Mesmo admitindo que "à luz dos novos elementos gerados no âmbito do pós-positivismo e da normatividade dos princípios, já não é mais possível afirmar, de modo peremptório, que

17 A esse respeito. Luís Roberto BARROSO assinala ainda que "em geral, a não previsão de cabimento do recurso hierárquico autoriza a conclusão de que ele não é cabivel". Na mesma linha, a lição de Celso Antônio BANDEIRA DE MELLO: "O controle administrativo ou tutela administrativa, segundo generalizada lição doutrinária, exerce-se nos limites da lei. Não se presume. Existirá quando, como e na forma prevista em lei" (Curso de direito administrativo, 1999. p. 147) apud BARROSO. Luís Roberto, 2002, Agências reguladoras. Constituição, transformações do Estado e legitimidade democrática. R. Dir. Adm., 229: 285-311. Jul./Set. 2002, p. 302.

I8 Barroso. Luís Roberto, 2002, Agências reguladoras. Constinuição, transformaçōes do Estado e legitimidade democrática. R. Dir. Adm., 229: 285-311, Jul./Set. 2002, p. 304. Aduz, ainda, este autor o seguinte: "Isto se dá, por exemplo, quando o Tribunal de Contas objetiva obter informações a respeito de deveres dos concessionários. atividades que, a par de não envolverem dispêndio de dinheiro público, constituem razão da criação da própria agência reguladora. Não the caberá avançar a atividade fiscalizadora sobre a atividade-fim da agência reguladora, sob pena de violação do princípio da separação de Poderes. Este, portanto, o limite da atribuição do Tribunal de Contas. Nada, rigorosamente nada, no texto constitucional o autoriza a investigar o mérito das decisões administrativas de umal autarquia. menos ainda de uma alutarquia com as características especiais de uma agência reguladora. Não pode o Tribunal de Contass procurar substituir-se ao administrador competente no espaço que a ele é reservado pela Constituição e pelas leis. O abuso seria patente. Aliás, nem mesmo o Poder Legislativo, órgão que é coadjuvado pelo Tribunal de Contas no desempenho do controle externo, poderia praticar atos dessa natureza ".

19 Art. $5^{\circ}-\mathrm{XXXV}$ da $\mathrm{CF} / 88$ : a lei não excluirá da apreciação do Poder Judiciário lesão ou ameaça de direito.

20 BARROSO, Luís Roberto, 2002, Agências reguladoras. Constituição, transformaçōes do Es. tado e legitimidade democrática. R. Dir. Adm.. 229: 285-311, Jul./Set. 2002, p. 305. 
o mérito do ato administrativo não é passível de exame", Luis Roberto BARROSO"! adverte que "a doutrina convencional em tema de controle dos atos administrativos, aí incluídos os das agências reguladoras, não perdeu a validade, mas sofre exceções importantes" 22 .

Assim, prevalecendo o entendimento segundo o qual as agências reguladoras não estão subordinadas hierarquicamente ao Poder Executivo ${ }^{23}$ e de que o controle dos atos de seus dirigentes por parte do Tribunal de Contas sofre as limitações acima descritas, estaria configurada a plena autonomia desses organismos em relação aos Poderes Constituídos, chegando-se à insólita conclusão de que a sociedade não dispõe

21 Segundo BARROSO, Luis Roberto: "Sem embargo, no tocante às decisões das agências reguladoras, a posição do Judiciário deve ser de relativa autocontenção, somente devendo invalidá-las quando não possam resistir aos testes constitucionalmente qualificados, como os de razoabilidade ou moralidade, já mencionados ou outros, como os da isonomia e mesmo o da dignidade da pessoa humana. Notadamente no que diz respeito a decisões informadas por critérios técnicos, deverá agir com parcimônia, sob pena de se cair no domínio da incerteza e dos subjetivismos" (BARROSO. Luís Roberto, 2002, Agências reguladoras. Consituição, transformações do Estado e legitimidade democrática. R. Dir. Adm.. 229: 285-311, Jul./Set. 2002, p. 306).

22 Em sentido contrário: FERRAZ JR., Tércio SAMPAIO. Como regular agências reguladoras? Folha de São Paulo, edição de 1.4.2003: "por sua (tradicional) impermeabilidade institucional, o Poder Judiciário deve ser levado a decidir sobre o mérito das regulaçōes (art. $5^{\circ}$., XXXV, tomado em sua plena extensão)"; SUNDFELD, Carlos Ari. Introdução às agências reguladoras, in Direito Administrativo Econômico, Malheiros, 2000, SUNDFELD, Carlos Ari (Coordenador), p. 26: “'A agência reguladora é necessariamente submetida aos controles parlamentar e judicial. Como sabem todos os que estudam o Direito Administrativo, o aspecto mais importante da relação do Poder Judiciário com a Administração Pública é o do controle judicial sobre todos os atos administrativos. A Administração Pública, aí incluídas as agências, tem de produzir e aplicar Direito na forma do Direito; e o Poder Judiciário vai controlá-lo" (grito no original); e MENDES, Conrado Hübner, Reforma do Estado e Agências Reguladoras: Estabelecendo os Parâmetros de Discussão, in Direito Administrativo Econômico, Malheiros, 2000, SUNDFELD, Carlos Ari (Coordenador), p. 130-131, concluindo pela inexistência de independências das agências reguladoras em relação ao Poder Judiciário: "divergem os administrativistas sobre a existência de uma esfera de discricionariedade imune ao controle judicial. A tendência caminha para a máxima limitação de tal esfera (notadamente nos pensamentos de Eros Roberto GRAU e Celso Antônio BANDEIRA DE MELLO). A contraargumentação, trazida dos americanos, que identifica tal esfera por se tratar de questões técnicas, não supera ou não consegue elidir o princípio da inafastabilidade do controle judicial. Isso é pacífico em nossa doutrina processual e mesmo administrativista: para julgar estes tipos de controvérsias o juiz faz uso da perícia judicial, que ao menos em tese, tem a função de trazer ao juiz os dados necessários que o tornem apto a tomar tal decisão. Não é falsa a afirmação da existência de um poder de dirimir conflitos no universo de competências da agência. Isto, porém, de maneira alguma afasta o princípio básico determinante em nosso sistemat político democrático, albergado pelo art. $5^{\circ}, \mathrm{XXXV."}$

23 No intuito de restringir a autonomia da ANATEL em relação ao Poder Executivo, o artigo 12, III do Decreto 4.635, de 21 de março de 2003. estabelece a competência do Departamento de Serviços e de Universalização de Telecomunicações, órgão vinculado ao Ministério das Comunicações, para "supervisionar as atividades da ANATEL, nos termos das políticas públicas definidas pelo Poder Executivo, zelando pela correta observância da política por parte da Agência Reguladora". 
de mecanismos de controle das agências, além do recurso à tutela jurisdicional, esta também sujeita a determinadas restrições, segundo parte da doutrina.

Em relação especificamente à função decisória dessas entidades, é curiosa a visão de alguns juristas que coloca a agência reguladora num patamar acima e eqüidistante em relação ao concessionário, ao usuário dos serviços e ao próprio Estado, como se, paradoxalmente, a agência constituísse um organismo não só à parte, mas também hierarquicamente superior ao aparelho estatal ${ }^{24}$ :

"identificamos no interior do processo decisório das agências ao menos três tipos de interesse em jogo: o interesse do próprio 'Estado', o interesse das 'empresas concessionárias' e o interesse dos 'usuários'. Desvelar qual destes é atendido numa decisão concreta da agência é de fundamental importância para não nos curvarmos à enunciação de um interesse público genérico. Terá le gitimidade democrática, portanto, a agência que der canais de representação a cada um destes interesses".

Nesse sentido, é emblemático o fato de diversas agências reguladoras, tanto do âmbito federal como do estadual, terem criado a "organização não-governamental" Associação Brasileira de Agências de Regulação - ABAR, pessoa jurídica de direito privado, sob a forma de associação civil.

A autonomia das agências reguladoras é mais expressiva ainda dado o seu poder normativo, ou seja, a atribuição concedida a esses órgãos, nas leis que os criaram, para expedir normas jurídicas. Trata-se, como admite Leila CUÉLLAR ${ }^{25}$, "de situação polêmica frente ao direito constitucional brasileiro, pois uma interpretação rígida dos princípios da separação dos poderes e da legalidade vedaria a possibilidade de detenção de poder normativo por parte das agências" ${ }^{26}$.

A legitimidade democrática desse modelo de Administração Pública é, supostamente, assegurada "por alguns aspectos que, idealmente, seriam capazes de neutralizar as consequiências do deficit democrático" 27 :

24 MENDES. Conrado Hiibner, Reforma do Estado e Agências Reguladoras: Estabelecendo os Parâmetros de Discussão, in Direito Administrativo Econômico, Malheiros, 2000, SUNDFELD, Carlos Ari (Coordenador), p. 131. No mesmo sentido: MARQUES NETO, Floriano Azevedo, $A$ Nova Regulação Estatal e as Agências Independentes, in Direito Administrativo Econômico, Malheiros, 2000, SUNDFELD, Carlos Ari (Coordenador), p. 85.

25 CUÉLLAR, Leila. As agências reguladoras e seu poder normativo. Dialética. São Paulo, 2001, p. 107.

26 Segundo Maria Sylvia Zanella di PIETRO (Direito Administrativo Brasileiro, $11^{\text {a }}$ ed., Atlas, 1999, p. 388-399): “Agência reguladora, em sentido amplo, seria no direito brasileiro, qualquer órgão da Administração Direta ou entidade da Administração Indireta com função de regular as matérias que thes estão afetas. Nesse sentido, a única coisa que constitui inovação é o próprio vocábulo, anteriormente não utilizado para designar entes da Administração Pública. A função normativa sempre foi exercida por inúmeros órgãos da Administração Pública, com maior ou menor alcance, com ou sem fundamento constitucional".

27 BARROSO, Luís Roberto, 2002, Agências reguladoras. Constituição, transformaçōes do Estado e legitimidade democrática. R. Dir. Adm., 229: 285-311, Jul./Set. 2002, p.309. 
"o Legislativo conserva o poder de criar e extinguir agências, bem como de instituir as competências que desempenharão; o Executivo, por sua vez, exerce o poder de nomeaçāo dos dirigentes, bem como o de traçar as políticas públicas para o setor específico; o Judiciário exerce o controle sobre a razoabilidade e sobre a observância do devido processo legal, relativamente às decisões das agências".

No entanto, não fica claro, como já assinalado, como é possível ao Executivo garantir o cumprimento das políticas públicas traçadas. em face da impossibilidade de demissão dos dirigentes das agências reguladoras.

Ainda em relação à legitimidade democrática desse modelo, Conrado Hübner MENDES admite que a alegação da doutrina americana, que a justifica pela simples nomeação dos dirigentes pelo Presidente da República, é por demais simplificadora ${ }^{28}$. Esse autor sustenta que "tal conceito de legitimidade democrática é muito mais amplo que a simples nomeação dos dirigentes" e passa por aquilo que houve por bem denominar "procedimentalização do agir do ente regulador": "a construção de um critério que paute a legitimidade democrática muito mais pelos procedimentos e pela transparência do que pelo mero mecanismo de acesso do dirigente ao seu cargo pode trazer uma verdadeira análise crítica".

Conrado Hübner MENDES identifica, ainda, na redação do art. $1^{\circ}$ da Constituição Federal - segundo o qual a República Federativa do Brasil tem como fundamentos, dentre outros, a cidadania e o pluralismo político - a possibilidade para a construção de uma interpretação que venha a "dar certa coloração jurídica à exigência de legitimidade democrática das agências reguladoras" 29 . Entretanto, longe de enfrentar a discussão acerca da constitucionalidade do modelo de independência das agências, este autor conclui, simplesmente, que a leitura "dogmática e conservadora" do texto constitucional leva a derrubar toda essa construção, razão pela qual se deva buscar uma interpretação constitucional que leve a "uma visão diferenciada do que seja e de qual seja a função do Direito" 30 .

Nesse sentido, é importante destacar que os únicos organismos da Administração Pública federal dotados de autonomia administrativa e de gestão financeira e patrimonial, por força da regra contida no art. 207 da Constituição Federal ${ }^{31}$, são as universidades e as instituições de pesquisa científica e tecnológica.

28 MENDES, Conrado Hübner, Reforma do Estado e Agências Reguladoras: Estabelecendo os Parâmetros de Discussão, in Direito Administrativo Econômico, Malheiros, 2000, SUNDFELD, Carlos Ari (Coordenador), p. 131-133.

29 MENDES, Conrado Hübner, Reforma do Estado e Agências Reguladoras: Estabelecendo os Parâmetros de Discussāo, in Direito Administrativo Econômico, Malheiros, 2000, SUNDFELD, Carlos Ari (Coordenador), p. 132.

30 MENDES, Conrado Hübner, Reforma do Estado e Agências Reguladoras: Estabelecendo os Parâmetros de Discussão, in Direito Administrativo Econômico. Malheiros, 2000, Sundfeld, Carlos Ari (Coordenador), p. 137-138.

31 Art. 207 da Constituição Federal: "As universidades gozam de autonomia didático-científica, administrativa e de gestão financeira e patrimonial, e obedecerão ao princípio de indissociabilidade entre ensino, pesquisa e extensão.

$\$ 2^{\circ} \mathrm{O}$ disposto neste artigo aplica-se às instituições de pesquisa científica e tecnológica." 
As agências reguladoras despontaram no cenário de abertura da economia brasileira e do processo de reforma do Estado, iniciado no Brasil, nos anos $90^{32}$. Esse modelo de administração pública, com variações importantes, vigora em diversos países do chamado primeiro mundo ${ }^{33}$.

Com o objetivo de avaliar os papéis dos órgãos reguladores, ministérios e instituições de defesa da concorrência no setor energético foi conduzido o estudo "Desenhos Institucionais de Regulação de Energia", coordenado pelo professor Helder Queiroz Pinto Jr., do Grupo de Economia da Energia, do Instituto de Economia da UFRJ.

Algumas das conclusões desse estudo foram sumarizadas na matéria publicada no jornal $\mathrm{O} \mathrm{Globo}^{34}$ e são transcritas a seguir:

"as agências reguladoras das áreas de energia elétrica, petróleo e gáso chamado setor energético - têm caracteristicas bem diversas em outros países. Em alguns, como os Estados Unidos elas têm muita força. Em outros casos, como na Bélgica, são subordinadas a algum ministério. No entanto, todas têm em comum a atribuição de regular, fixar tarifas e fiscalizar o setor energético. Outra característica em comum é que todas, sem exceção, seguem as diretrizes gerais da política energética de seus governos. Países como a Alemanha e o Japão, contudo, não têm agências reguladoras".

"Nenhuma agência nos países pesquisados é independente porque, de uma forma ou de outra, têm que prestar contas ao governo federal ou estadual,

32 "Os princípios básicos que levaram à criação das agências reguladoras - nas economias desenvolvidas do mundo, há décadas, e no Brasil, desde meados dos anos 90 - são, em primeiro lugar, o interesse do cidadão-usuário (ou consumidor) de contar com serviços públicos (privatizados) da melhor qualidade que possa oferecer a tecnologia disponivel, e, em segundo lugar, a garantia dos investidores de que não haverá desrespeito a contratos firmados ou às regras pré-estabelecidas, que motivaram seus respectivos investimentos" (Editorial de O Estado de São Paulo, de 28 de março de 2003).

33 De acordo com Helder Queiroz PINTO Jr.. "os fundamentos institucionais da tradição regulatória norte-americana são baseados na criação de instituições independentes especializadas (em geral multi-setoriais) exercendo simultancamente funções legislativas, administrativas e quasi-judiciais. O exercício simultâneo dessas funções é justificado, segundo a tradicional literatura sobre regulação, pela necessidade de expertise em questões envolvendo aspectos técnicos complexos. Além disso, essa característica reforça o poder decisório dos órgãos reguladores norte-americanos. Já a tradição européia é muito distinta. A tendência ná Europa tem sido colocar a ênfase da ação reguladora em apenas uma dessas funções, deixando os demais a cargo de outras instituições. Essa constatação amplia a variedade de formas de regulação e explica, além disso, a dificuldade das abordagens comparativas e das tentativas de replicar os modelos institucionais em outros países". (Desenhos Institucionais e a Regulação de Energia. Conjuntura \& Informação. n 17, 2002, ANP, p.12).

34 ORDOÑEZ, Ramona. Agências não são independentes, O Globo, edição de 2/3/2003, p.21. 
seguindo as diretrizes para o setor. Todos os outros paises se inspiraram no modelo americano, embora nem todos os órgãos tenham funções dos três poderes."

"Em todos os paises pesquisados, independentemente do grau de autonomia que as agências têm, elas seguem as diretrizes da política macroeconômica dos governos federais para os quais prestam contas."

Os comentários acima são suficientes para se concluir que o legislador brasileiro inovou a disciplina das agências reguladoras ao estender a autonomia desses órgãos em relação ao Poder Executivo além dos limites praticados na maior parte dos países pesquisados. O trabalho foi realizado a partir do estudo da legislação de 25 países, dentre os quais se incluem Argentina, Alemanha, Austrália, Bélgica, Canadá, Dinamarca, Espanha, Estados Unidos, Inglaterra, Itália, Japão, França e México.

\section{As propostas de alteraçōes legislativas em tramitação no Câmara e no Senado}

O saldo de toda essa reflexão, neste momento, aponta, inequivocamente, na direção da necessidade de revisão, ao menos parcial, do modelo de plena autonomia das agências reguladoras.

Nessa linha, mesmo os mais extremados liberais admitem que "ninguém contesta o direito e o dever de o Estado traçar as diretrizes e planejar, a longo prazo, o desenvolvimento dos setores estratégicos" 35 , assim como defensores do paradigma em vigor reconhecem que "se couber às agências a determinação integral das políticas públicas do setor regulado, pouco restará ao Chefe do Executivo em termos de competência decisória, valendo lembrar que é ele quem detém a legitimidade democrática, recebida nas eleições, para exercer a função administrativa" ${ }^{36}$. No mesmo compasso, Joaquim Benedito Barbosa GOMES acrescenta:

35 Editorial de O Estado de São Paulo, de 28 de março de 2003.

36 BARROSO, Luís Roberto, 2002, Agências reguladoras. Constituição. transfornações do Estado e legitimidade democrática. R. Dir. Adm., 229: 285-311, Jul./Set. 2002, p.302. Ainda segundo Luis Roberto Barroso: "É possível mesmo vislumbrar um cenário no qual a multiplicação das agências, cada qual dotada de completa independência em relação ao Executivo, acabaria por esvaziar o espaço decisório que lhe cabe constitucionalmente. Como se vê, os parâmetros dessa relação ainda deverão ser fixados". No mesmo sentido, a reflexão de Alexandre Santos Aragão: "todavia, a adoção de um modelo multiorganizativo ou pluricêntrico de Administração Pública traz riscos à legitimidade democrática da sua atuação. Em outras palavras, uma das suas maiores vantagens - a distância dos critérios político-partidários de decisão, assegurada, sobretudo, pela impossibilidade do Chefe do Poder Executivo (eleito) exonerar livremente os seus dirigentes (nomeados) - é também um dos seus maiores riscos". Há, contudo, algumas manifestações em contrário, como a de Celso Campilongo, membro do CADE, no sentido de que "[a] independência do CADE só pode ser entendida como a capacidade de imunização contra qualquer ingerência do Governo. Não há nem relaçāo de tutela e, muito menos, de orientação do Governo ao CADE. É no interesse do próprio Estado - e da coletividade definida como titular dos bens jurídicos protegidos 
"advirta-se, contudo, que não basta conferir estabilidade aos dirigentes de uma agência para que ela automaticamente passe a ser "independente". Mesmo nos EUA, onde o Congresso exerce com zelo implacável a atribuição hoje crucial de todo órgão legislativo (a físcalização e o controle), e em que o sistema de 'checks and balances' funciona com razoável eficiência, não são raras as críticas de que as agências, ao invés de atuarem em busca do cumprimento do interesse público, procuram preferencialmente atingir seus próprios interesses e os de lobbies eficazmente incrustados e com atuação concertada, tanto nos comitês do Congresso incumbido de supervisioná-las, quanto no âmbito das atividades privadas que lhes incumbe regulamentar $\mathrm{e}$ fiscalizar ${ }^{37}$ Noutras palavras, é sério o risco de, ao se retirar as agências do âmbito de influência da Política, submetê-las ao jugo de forças econômicas poderosas" ${ }^{38}$.

Neste contexto, foram apresentados dois projetos de lei no intuito de disciplinar a questão do controle das agências reguladoras.

O Projeto de Lei do Senado $\mathrm{n}^{\circ} 38$, de 2003, de autoria do Senador Arthur Virgilio, altera a Lei $n^{\circ} 9.986$, de 18 de julho de 2000 , que "dispõe sobre a gestão de recursos humanos das Agências Reguladoras e dá outras providências", instituindo o controle externo das Agências Reguladoras. $\mathrm{O}$ art $1^{\circ}$ do referido projeto de lei assim estatui:

"Art. $1^{\circ}$ A Lei no 9.986, de 18 de julho de 2000, que "dispõe sobre a gestão de recursos humanos das Agências Reguladoras e dá outras providências", passa a vigorar acrescida dos seguintes artigos:

Art. 10-A. As Agências Reguladoras terão suas atividades submetidas ao exame e sugestōes do órgão competente de controle externo

Art. 10-B. O controle e fiscalização externos das atividades das Agências Reguladoras serão exercidos pelo Poder Legislativo na forma a ser estabelecida em ato do Congresso Nacional.

$\S 1^{\circ}$ Integrarão o órgão de controle externo das atividades das Agências Reguladoras os líderes da maioria e da minoria na Câmara dos Deputados

pela Lei $\mathrm{n}^{\circ} 8.884$ - que se fixa a independência organizativa (em relação ao Governo) e funcional (das decisões) do CADE", ainda que, "a independência do CADE não se confunde com 'soberania' e muito menos com a ausência de liames de coordenação com os diversos setores do Governo" (voto no Ato de Concentração n ${ }^{\circ}$ 08012.006762/2000-09), apud Souza, Telma, Justificativa do PL $413 / 2003$, p. 8 .

37 Wilson, V.J., The Politics of Regulation, 1980; Stewart, Richard B., Madison's Nightmare, University of Chicago Law Review, 335/57, 1990, apud GOMES, Joaquim B. Barbosa, Agências Reguladoras: A "Metamorfose" do Estado e da Democracia, Revista de Direito da Associação dos Procuradores do Novo Estado do Rio de Janeiro, vol. XI, 2002, ARAGĀO, Alexandre Santos (coord.). Lumen Juris, p. 107.

38 GOMES, Joaquim B. Barbosa, Agências Reguladoras: A "Metamorfose" do Estado e da Democracia, Revista de Direito da Associação dos Procuradores do Novo Estado do Rio de Janeiro, vol. XI, 2002, Aragão, Alexandre Santos (coord.), Lumen Juris, p. 107. 
e no Senado Federal, assim como o presidente da Comissão de Infra-Estrutura do Senado Federal e o presidente da congênere Comissão Permanente da Câmara dos Deputados.

$\$ 2^{\circ} O$ ato a que se refere o 'caput' deste artigo definirá o funcionamento do órgão de controle e a forma de desenvolvimento dos seus trabalhos com vistas ao controle e fiscalização dos atos decorrentes da execução das atividades das Agências Reguladoras". ${ }^{39}$

Em que pese o mérito da iniciativa, no sentido de estabelecer uma forma de controle externo das agências reguladoras como previsto no art. 70 da Constituição Federal, a regra contida no art. $1^{\circ}$ do PL $n^{\circ} 38 / 2003$ do Senado Federal apenas restaura parcialmente o espírito do art. 50 da Constituição Federal, esvaziado pela autonomia das agências reguladoras em face do Poder Executivo, conferida pela regra do art. $9^{\circ}$ da Lei $9.986 / 00$. O art. 50 da Constituição Federal permite que a Câmara Federal ou o Senado Federal, suas respectivas Mesas, bem como qualquer de suas Comissões solicitem informaçōes a Ministros de Estado ou quaisquer titulares de órgãos diretamente subordinados à Presidência da República, enquanto que o PL $n^{\circ} 38 / 2003$ concede a prerrogativa de controle e fiscalização das atividades das agências reguladoras a apenas uma comissão mista específica do Congresso Nacional.

Com o mesmo propósito do PL n 38/2003 do Senado Federal, qual seja o de criar mecanismos de controle para as agências reguladoras, porém com solução e pressupostos absolutamente distintos, foi apresentado o Projeto de Lei da Câmara dos Deputados $n^{\circ} 413 / 2003$, de autoria da Deputada Telma de Souza, cujo art. $3^{\circ}$ é reproduzido a seguir:

"Art. $3^{\circ}-O$ art. $9^{\circ}$ da lei $n^{\circ} 9.986$, de 18 de julho de 2000, passa a vigorar com a seguinte redação:

Art. $9^{\circ}-A$ exoneração dos Conselheiros e dos Diretores poderá ser promovida pelo Chefe do Poder Executivo em qualquer época, observado o disposto neste artigo.

39 Na Justificação desse projeto de lei, o Senador Arthur Virgílio sustenta que: "A quebra dos monopólios e o processo de privatização trouxeram uma nova função para o Estado brasileiro, a de atuar, de forma efetiva, na fiscalização e regulação dos serviços públicos, agora prestados, em grande parte, por empresas privadas. Para se desincumbir dessa obrigaçāo, a Administração Pública instituiu uma nova entidade, a agência reguladora, caracterizada como uma autarquia em regime especial, com papel normativo e fiscalizador e dotada de autonomia, não estando subordinada diretamente à hierarquia administrativa ordinária. Os dirigentes das agências reguladoras são detentores de mandato e não estāo submetidos ao seu Ministro de Estado supervisor, única autoridade que, de acordo com a vigente Carta Magna, tem obrigação de comparecer perante os órgãos do Poder Legislativo para prestar esclarecimentos a respeito das matérias sob sua área de competência, bem como de responder a requerimento de informações. Faz-se, assim, necessário, que o Poder Legislativo exerça a sua capacidade fiscalizadora diretamente sobre as atividades das agências reguladoras para que elas possam desempenhar, de forma adequada, as suas atribuições." (Diário do Senado Federal, edição de 27 de fevereiro de 2003, p. 02564-02565). 
$\S I^{\circ}$ - Constituem motivos para a exoneração de dirigentes das Agências, em qualquer época a prática de ato de improbidade administrativa; a condenação penal transitada em julgado, o descumprimento injustificado do contrato de gestão, e a não observância das políticas determinadas pelo Ministério ou Órgão Superior.

$\$ 2^{\circ}$ - A lei de criação da Agência poderá prever outras condições para a perda do mandato" 40 .

Na Justificativa do PL n 413/2003 da Câmara dos Deputados, elaborada com a contribuição de Eros Roberto GRAU, sustenta-se que a ausência de subordinação hierárquica das agências reguladoras constitui afronta ao art. 84, II da Constituição Federal $^{4 !}$.

Em síntese, o PL n $413 / 2003$ da Câmara dos Deputados, se tornado lei, limitará a autonomia das agências reguladoras, sem contudo restabelecer a possibilidade da

40 O PL 413/2003 da Câmara dos Deputados traz ainda três importantes inovações no regime jurídico das agências reguladoras:

a) Art. $1^{\circ}: 0$ inciso VI do art. $3^{\circ}$ da Lei $9.427 / 96$ passa a estabelecer a necessidade aprovação prévia do Ministério de Estado de Minas e Energia para a fixaçīo, pela ANEEL. dos critérios de cálculo do preço de tratnsporte de que trata o $\$ 6^{\circ}$ do art. 15 da Lei 9.074/95:

b) Art. $2^{\circ}: 0 \$ 2^{\circ}$ do art. $8^{\circ}$ da Lei $9.472 / 97$, que estabelece a natureza de autarquiat especial da ANATEL, passa a não mais incluir a característica de "ausência de subordinação hierárquica" desta agência, permanecendo entretanto as características de "independência administrativa", "mandato fixo" e "autonomia financeira":

c) Art. $2^{\circ}: 0$ art. 24 da Lei $9.472 / 97$ passa a prever o mandato de quatro (em vez de cinco) anos para os membros do Conselho Diretor da ANATEL.

41 Destacam-se na Justificativa do PL n 413/2003 da Câmara dos Deputados, as seguintes considerações: "é gritantemente evidente que a independência [= ausência de subordinação hierárquica] das autarquias não as coloca à margem do aparato estatal, de modo a legitimar o exercício, por elas, de atuação adversa às políticas públicas governamentais. Assim, ainda que se possa admitir que as autarquias especiais não estejam organicamente integradas na administração ordinária do Estado, não se as pode conceber como entidades desgarradas do aparato estatal e, nele, da Administração. Elas não estão legitimadas a, excedendo os estritos limites de suas atribuições, constituir uma outra Administração [a administração das tais 'políticas de Estado', intocáveis pelo governo!], paralela à autêntica Administração. E, menos ainda, podem atuar à margem das regras e dos princípios do Direito Administrativo Brasileiro, quanto menos do que define a Constituiçāo do Brasil". "Sua qualificação como autarquias sob regime especial decorreria da circunstância de lhes ser assegurada [i] ausência de subordinação hierárquica, [ii] independência ou autonomia administrativa, financeira, patrimonial, de gestão de recursos humanos e técnica e [iii] mandato fixo e estabilidade de seus dirigentes. Ocorre que todas essas características são próprias e peculiares às autarquias, salvo as duas últimas [mandato fixo e estabilidade de seus dirigentes]. Mas essas inovações são franca e irremediavelmente inconstitucionais. A suposição de que auxiliares menores do chefe do Poder Executivo. dirigentes de autarquias, não possam ser por ele livremente nomeados e exonerados é incompatível como regime presidencialista. $\mathrm{O}$ artigo 84 , II da Constituição do Brasil afirma ser da competência privativa do Presidente da República o exercício da direção superior da administração federal. Daí ser absurda a idéia de que os dirigentes de autarquias seriam titulares de direito a serem mantidos em seus cargos além de um mesmo período governamental" (grifo no original). 
demissão ad nutum de seus dirigentes por parte do Chefe do Poder Executivo, o que, a rigor, é garantido pela diç̧ão do art. 37, Il da Constituição Federal. como discutido acima. Assim, a par das hipóteses previstas na norma contida no art. $9^{\circ}$ da Lei 9.986/00 - renúncia, condenação penal transitada em julgado ou de processo administrativo disciplinar - os conselheiros e os diretores serão exonerados, em qualquer época, em caso de descumprimento injustificado do contrato de gestão ou de não observância das políticas determinadas pelo Ministério ou Órgão superior.

\section{Conclusão}

Se, por um lado, é forçoso admitir que "as agências reguladoras tornaram-se peças fundamentais no ambicioso projeto nacional de melhoria da qualidade dos serviços públicos e de sua universalização, integrando ao consumo, à cidadania e à vida civilizada enormes contingentes mantidos à margem do progresso material" ${ }^{42}$, é importante verificar também, que a adoção do modelo de autonomia irrestrita dessas entidades conduz ao paradoxo da coexistência de "administrações paralelas", no âmbito da Administração Pública ${ }^{43}$.

Fundamental, também, a reflexão acerca da ponderação de Carlos Ari SUNDFELD sobre o tema ${ }^{44}$ :

"É inevitável reconhecer que a defesa apaixonada de um modelo de agências independentes pode carregar, no mínimo, uma forte carga de ingenuidade. Protótipos abstratos costumam gerar monstrengos no mundo real, cujas complexidades com freqüencia se encarregam de distorcer, mesmo sem negá-los explicitamente, todos os belos princípios de que se partiu. Sonhar com autoridades equilibradas, imparciais, tecnicamente prepara-

42 BARROSO, Luís Roberto, 2002, Agências reguladoras. Constituição, transformações do Estado e legitimidade democrática. R. Dir. Adm., 229: 285-311, Jul./Set. 2002, p. 311.

43 Nesse sentido, vale lembrar a manifestação de Celso Antônio BANDEIRA DE MELLO: "Há mais de trinta anos passados, com muito menor vivência, acreditava também que isto [a 'autonomia", 'independência' de certas pessoas da administração indireta] seria útil para preservar uma atuação 'técnica', que é o argumento habitual usado para defesa deste ponto de vista. Embora existam realmente casos de decisões estritamente 'técnicas', o fato é que a atuação de uma pessoa da administração indireta como um todo - e mesmo muitas de suas 'decisões técnicas' - dependem essencialmente de uma diretriz política. Eis por que não é possível, sem desvirtuar a essência de um regime democrático, conferir tamanha 'autonomia' a estas parcelas da Administração. Com efeito, para se constituírem em canais expressivos de tal regime, terão de refletir a orientação política encarnada no partido que haja vencido as eleições. Por isto mesmo são inadmissíveis os 'mandatos a prazo certo' que se estendam além do período governamental de quem nomeou os dirigentes destas entidades da administração indireta." In [Internet] http://www.migalhas.com.br/mig_imprimir2.aspx?cod_materia= 1041 .

44 SUNDFELD, Carlos Ari. Introdução às agências reguladoras, in Direito Administrativo Econômico, Malheiros, 2000, SUNDFELD. Carlos Ari (Coordenador), p. 25. 
das, democráticas, comprometidas com os interesses gerais, respeitadoras do Direito etc., em nada garante que a realidade vá se ajustar aos sonhos."

Por fim, é importante assinalar que a garantia de estabilidade dos dirigentes dessas agências, sustentada pela regra contida no art. $9^{\circ}$ da Lei $9.986 / 00$, vai de encontro aos seguintes dispositivos da Constituição Federal:

a) art. $2^{\circ}$ : "São poderes da União, independentes e harmônicos entre si, o Legislativo, o Executivo e o Judiciário."

b) art. 37, II: "a investidura em cargo ou emprego público depende de aprovação prévia em concurso público de provas ou de provas e títulos, ressalvadas as nomeações para cargo em comissão declarado em lei de livre nomeação e exoneração;"

c) art. 70 (parte final): "A fiscalização contábil, financeira, orçamentária, operacional e patrimonial da União e das entidades da administração direta e indireta, quanto à legalidade, legitimidade, economicidade, aplicação das subvenções e renúncia de receitas, será exercida pelo Congresso Nacional, mediante controle externo, e pelo sistema de controle interno de cada Poder."

d) art. 84, II: "Compete privativamente ao Presidente da República exercer, com o auxílio dos Ministros de Estado, a direção superior da administração federal;"

e) art. 84, VI: "Compete privativamente ao Presidente da República dispor sobre a organização e o funcionamento da administração federal, na forma da lei;"

f) art. 87, parágrafo único, I: "Compete ao Ministro de Estado, além de outras atribuições estabelecidas nesta Constituição e na lei exercer a orientação, coordenação e supervisão dos órgãos e entidades da administração federal na área de sua competência e referendar os atos e decretos assinados pelo Presidente da República;"

Adicionalmente, a autonomia das agências reguladoras, garantida pela estabilidade de seus dirigentes nos termos do art. $9^{\circ}$ da lei 9.986/00, torna inócuas, em relação às atividades abrangidas por estes órgãos, as regras contidas nos seguintes dispositivos constitucionais:

a) Art. 50: "A Câmara dos Deputados e o Senado Federal, ou qualquer de suas Comissões, poderão convocar Ministro de Estado ou quaisquer titulares de órgãos diretamente subordinados à Presidência da República para prestarem, pessoalmente, informações sobre assunto previamente determinado, importando em crime de responsabilidade a ausência sem justificação adequada."

b) Art. 50, § 20: "As Mesas da Câmara dos Deputados e do Senado Federal poderão encaminhar pedidos escritos de informação a Ministros de Estado ou a qualquer das pessoas referidas no caput deste artigo, importando em crime de responsabilidade a recusa, ou o não atendimento, no prazo de trinta dias, bem como a prestação de informações falsas."

Nesse contexto, as alterações propostas têm o mérito de restaurar o respeito ao princípio da separação dos Poderes e dos demais dispositivos constitucionais acima relacionados, ao mesmo tempo em que preservam, dentro de um critério de razoabilidade, elevado grau de autonomia das agências reguladoras, desejável para o bom desempenho das funções para as quais foram criadas. 
Aragão, Alexandre Santos, 2001, A função e a posição das agências reguladoras no Estado contemporâneo, Dissertação de Mestrado.

Ariño, Gaspar, 1993, Economia y Estado, Buenos Aires, Abeledo-Perrot.

Bandeira de Mello, Celso Antônio In [Internet] http://www.migalhas.com.br/ mig_imprimir2.aspx?cod_materia $=1041$.

Bandeira de Mello, Celso Antônio, 2002, Curso de Direito Administrativo, Malheiros., $14^{\mathrm{a}} \mathrm{ed}$.

Barroso, Luís Roberto, 2002, Agências reguladoras. Constituição, transformaçōes do Estado e legitimidade democrática. R. Dir. Adm., 229: 285-311.

Capilongo, Celso, voto no Ato de Concentração $n^{\circ}$ 08012.006762/2000-09.

Cuéllar, Leila. As agências reguladoras e seu poder normativo, 200I, Dialética. São Paulo.

Di Pietro, Maria Sylvia Zanella, Direito Administrativo Brasileiro, $11^{\text {a }}$ ed., Atlas, 1999.

Ferraz Jr., Tércio Sampaio. Como regular agências reguladoras? Folha de São Paulo, edição de 1.4.2003.

Gomes, Joaquim Benedito Barbosa, Agências Reguladoras: A "Metamorfose" do Estado e da Democracia, Revista de Direito da Associação dos Procuradores do Novo Estado do Rio de Janeiro, vol. XI, 2002, Aragão, Alexandre Santos (coord.), Lumen Júris.

Marques Neto, Floriano Azevedo, A Nova Regulação Estatal e as Agências Independentes, in Direito Administrativo Econômico, Malheiros, 2000, Sundfeld, Carlos Ari (Coordenador).

Mendes, Conrado Hübner, Reforma do Estado e Agências Reguladoras: Estabelecendo os Parâmetros de Discussão, in Direito Administrativo Econômico, Malheiros, 2000, Sundfeld, Carlos Ari (Coordenador).

O Estado de São Paulo, Editorial de 28.3.2003.

Ordoñez, Ramona. Agências não são independentes, O Globo, edição de 2.3.2003.

Pinto Jr., Helder Queiroz, Desenhos Institucionais e a Regulação de Energia, Conjuntura \& Informação, ${ }^{\circ} 17,2002$, ANP.

Salomoni, Jorge Luis, 1999, Teoria General de los Servicios Públicos, Buenos Aires, Editorial Ad Hoc/Villela Editor.

Souto, Marcos Juruena Vilela, Agência Reguladoras, R. Dir. Adm., 216: 125-162, 1999.

Souza, Telma, Justificativa do PL 413/2003.

Stewart, Richard B., Madison's Nightmare, University of Chicago Law Review, $335 / 57,1990$.

STF, Informativo, Brasília, 15 a 19 de novembro de $1999-\mathrm{n}^{\circ} 171$.

Sundfeld, Carlos Ari. Introdução às agências reguladoras, in Direito Administrativo Econômico, Malheiros, 2000, Sundfeld, Carlos Ari (Coordenador).

Wilson, V. J., The Politics of Regulation, 1980. 


\section{Aspectos Modernos do Direito Societário}

Nelson Eizirik

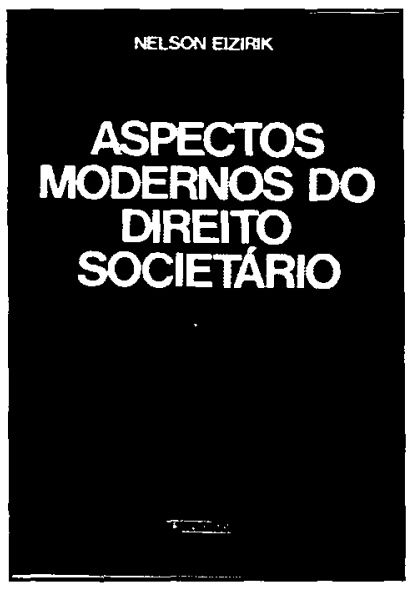

Esta obra reúne parte dos estudos e pareceres de Direito Societário e mercado de capitais escritos nos últimos quatro anos pelo autor, quase todos inéditos. A eventual modernidade da obra é dada pelos temas que a compóem - ainda pouco analisados na doutrina nacional - e pela abordagem utilizada, na qual os institutos jurídicos sāo estudados tendo em vista, sua função econômica.

Ref. 0038

Form. 14x21

Brochura

1992

238 págs.

\section{As Sociedades Cooperativas e a sua Disciplina Jurídica}

Nesta obra o autor tem o intuito de esclarecer, de um lado, a situação jurídica das sociedades cooperativas no Brasil e, de outro, além das lições da doutrina cooperativista, também os problemas que as assoberbam, necessitando constantemente de seguidos esclarecimentos.

Waldirio Bulgarelli

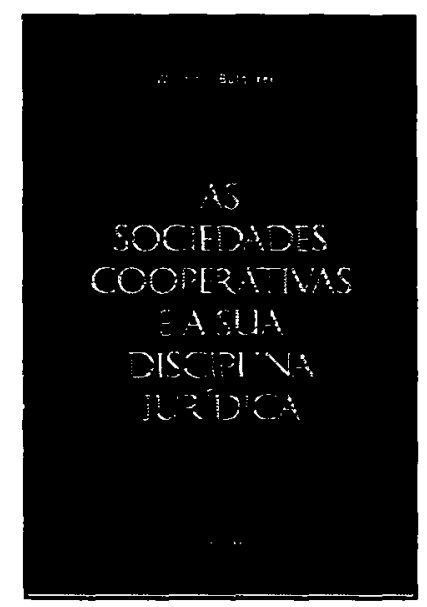

$\begin{array}{llr}\text { Ref. 0186 } & \text { Brochura } & 392 \text { págs. } \\ \text { Form. 14x21 } & 1998 & \end{array}$

